\title{
Sexual and Gender Diversity, National State and Biopolitics in the Global South: Lessons from Africa
}

\section{Fabiano Gontijo}

\section{(2) OpenEdition}

1 Journals

\section{Electronic version}

URL: https://journals.openedition.org/aa/8320

DOI: $10.4000 / a a .8320$

ISSN: 2357-738X

\section{Publisher}

Programa de Pós-Graduação em Antropologia Social (UnB)

\section{Printed version}

Number of pages: 97-126

ISSN: 0102-4302

\section{Electronic reference}

Fabiano Gontijo, "Sexual and Gender Diversity, National State and Biopolitics in the Global South: Lessons from Africa", Anuário Antropológico [Online], v.46 n.2 | 2021, Online since 30 May 2021, connection on 01 June 2021. URL: http://journals.openedition.org/aa/8320 ; DOI: https://doi.org/ 10.4000/aa.8320

\section{(9) $\odot \Theta \Theta$}

Anuário Antropológico is licensed under a Creative Commons Atribuição-Uso Não-Comercial-Proibição de realização de Obras Derivadas 4.0 International. 


\title{
anuário antropológico \\ (c) (1) \\ v. $46 \cdot \mathrm{n}^{\circ} 2 \cdot$ maio-agosto $\cdot 2 \odot 21.2$
}

\section{Sexual and Gender Diversity, National State and Biopolitics in the Global South: Lessons from Africa}

DOI: https://doi.org/10.4000/aa.8320

\author{
Fabiano Gontijo \\ Universidade Federal do Pará, Instituto de Filosofia e Ciências Humanas, Faculdade de \\ Ciências Sociais, Programa de Pós-Graduação em Antropologia, Belém, PA, Brasil \\ Tenure Professor in Federal University of the State of Pará, Brazil. Ph.D. in Anthropology, École des Hautes \\ Études en Sciences Sociales. Researcher, National Council for Scientific and Technological Development, \\ Brazil.
}

In the last 25 years, a considerable number of texts by African researchers have been published dealing with the expressions of gender and sexual gender diversity on the African continent from the perspective of the social sciences. The texts have in common the relationship they present between sexuality, national state, and globalization, considering the effects of colonialism, imperialism, and capitalism. I intend here to present a summary of the main ideas developed in some of these publications to a public of Portuguese-speaking readers in order to promote some comparative reflections on sexuality in the Global South. 


\section{Presentation}

What can we learn from African studies on the expressions of sexual and gender diversity? ${ }^{1}$ Since the 1990s, there has been a profusion of critical and reflexive anthropological publications (as well as sociological, historical, and literary ones) on the subject of sexuality on the continent (and almost always associated with the subject of gender), most of them authored by African researchers. In general, these publications have as a backdrop, three widespread ideas: 1) post-colonial Africa is a homophobic environment; 2) non-normative sexual practices and identities and "homosexuality" are exogenous to the continent and would have been brought there by the Arab-Muslim and European-Christian colonization processes; and 3) African people are lustful and their bodies are "naturally" erotic objects (Epprecht, 2008a, 2008b; Mbisi, 2011). These publications, thus, start by denouncing the overly universalist and regulating (western) character of the first argument, the overly culturalist and nationalizing character of the second, and the racist and essentializing character of the last. In all cases, neither the particularities of the corporalities and expressions of sexual and gender diversity in the very diverse African territory, nor their relationship with complex contemporary transnational cultural dynamics, would be taken into account (Hoad, 2007) ${ }^{2}$.

In fact, the category "homosexuality" can be considered as exogenous to African history, since it was forged in the European context of consolidation of the modern national state, arising from medical-scientific and legal-moral discursivities that established heteronormativity, sexual dimorphism, and compulsory heterosexuality as biopolitical bases for sustaining national ideologies. The biopolitical dispositives thus instituted served to discipline the bodies according to the capitalist needs of production and reproduction of workers in bourgeois societies. These discursivities, without ceasing to be forged by religious and pastoral morality - although in theory opposed to Christian theology - contributed to the legitimization of Euro-North American colonial, imperial and capitalist expansionist projects throughout the $19^{\text {th }}$ and $20^{\text {th }}$ centuries, imbued with a declared civilizing mission (Elias, 1994) and disciplining bodies under the auspices of modern governmentality (Foucault, 2004a, 2004b) ${ }^{3}$.

The decolonization and the "new world order" of the world-system (Wallerstein, 2006), from the second half of the $20^{\text {th }}$ century, led the African nations to adopt the Western state model with the maintenance of much of its ideological structuration based on those biopolitical dispositives of modern governmentality, albeit with significant nuances, including the preservation of the religious morality of colonization, hence the defense, by these new rulers and government institutions, of the supposed exogeny of sexual and gender diversity and the consequent development of homophobic purposes ${ }^{4}$.

Part of the postcolonial African national elites, under the logic of the modern world-system directed from the Global North, found themselves faced with the injunction to reinforce the metaphysics of difference (Mbembe, 2000, 2001), that is, the particularism of the common African experience or the exceptional conti-
1 I acknowledge Igor Erick (Ph.D. student, PPGA/UFPA) for his valuable comments, Joanna Troufflard for the review of the English version, and the Brazilian National Council for Scientific and Technological Development (CNPq) for the Research Grant.

2 The term experiences of sexual and gender diversity will be used to refer to sexual and/or gender practices and identities and their multiple social and cultural dynamics (sometimes the term expression of sexual and gender diversity will be used to emphasize the eloquent and vivid character of the practices and identities); non-normative sexuality designates those experiences of sexual and gender diversity that are locally considered not to correspond to established social, moral, and sometimes legal expectations and are therefore amenable to some form of regulation; and finally, alternative sexuality, when experiences are "other" than normative ones, but not necessarily amenable to framing. Homosexuality (as well as the terms lesbian, gay, bisexual, transsexual, transgender, intersexual, etc.) is the Western term most commonly used by international institutions (some non-governmental organizations, the United Nations, the African Union, etc.), also widely used by African governments and activists, among others.

3 By governmentality, Foucault (2004a, p. 111-112) understands "[...] the set constituted by institutions, the procedures, analyses and reflec tions, the calculations and the tactics which make it possible to exercise this very specific, although a very complex form of power that has for the main target the population, [has] for a major form of knowledge the political economy, [has] for essential technical instrument the security dispositives [...]"; and $[. .$.$] the tendency, the$ tug-of-power which, throughout the West, has not ceased to lead, and for a very long time, towards the preeminence of this type of power called 'govern- 
nental singularity in relation to the rest of the planet. This occurred both by naturalizing the universal subordination of women and by essentializing primordial African patriarchalism (which was denounced by Oyěwùmí, 1997, with the counterpoint of Bakare-Yusuf, 2003), as well as by invisibilizing traditionally prevailing sexual practices and identities and questioning the new expressions of sexual and gender diversity-related to contemporary transnational cultural dynamics (which was denounced by Mbisi, 2011).

Recent publications on sexual and gender diversity on the continent have been showing precisely the creative ways of counterposing an epistemology of resistance (Dorlin, 2009) against European epistemologies of sexuality (Jaunait et al, 2013). This literature confronts the harmful effects of the metaphysics of difference and one of its main prerogatives, characterized by Mbembe (2006) as the potentat sexuel, that is, a phallocratic regime of truth with persistent moral assumptions of colonialism, markedly Christian and Islamic.

The publications on sexuality in African contexts have produced critical and reflexive theorizations that confront heteronormative cultural arbitraries (especially those of colonial origin, but not only) that persist in the national projects in force on the continent and are materialized in the discourses of political, religious and legal leaders. Moreover, they also allow us to understand the new forms of neoliberal universalisms of international institutions (above all, non-governmental organizations and instances of the United Nations), which under the pretext of combating AIDS or the supposedly "natural” homophobia of the continent, promote actions considered as dangerously salvationist or victimizer.

These publications - resulting from empirical research, activist reflections, and artistic interventions - seem to promote a very fertile dialogue among the people involved in almost the entire continent, although the reflections are predominantly produced from English-speaking countries. The confluence of the critical and reflexive purposes of these publications is also noteworthy, despite the diversity of historical experiences, social contexts, political situations, or economic impacts of the insertion in the world-system that configure cultural arrangements very peculiar to each country.

This paper aims to offer short general comments about some of these publications originally in English and French to provoke comparisons between these researches and those carried out in the Americas and elsewhere. To this end, I will present, at first, a brief reflection on the historical and anthropological construction of African bodies as abject, racialized, eroticized and exoticized, paradoxical objects of desire and repudiation, but always objects of control, which would have justified colonization, through the civilizing process. The racialized sexual ideology persists to this day as a way of ratifying coloniality itself. Secondly, I will describe some of the most thought-provoking publications on sexual and gender diversity in African contexts that react to racialized sexual ideology. From these publications and timidly relating them to discussions produced in other areas, I will elaborate some considerations on the relations between state, nation, biopolitics, and sexuality in the Global South, in order to reinforce the reflections on the ment' on all the others [...]." Free translation from French: “[...] l'ensemble constitué par les institutions, les procédures, analyses et réflexions, les calculs et les tactiques qui permettent d'exercer cette forme bien spécifique, quoique très complexe, de pouvoir qui a pour cible principale la population, pour forme majeure de savoir l'économie politique, pour instrument technique essentiel les dispositifs de sécurité [...]"; and "[...] la tendance, la ligne de force qui, dans tout l'Occident, n'a pas cessé de conduire, et depuis fort longtemps, vers la prééminence de ce type de pouvoir qu'on peut appeler le "gouvernement" sur tous les autres [...]." By dispositive, Foucault understands the heterogeneous set that encompasses "[...] discourses, institutions, architectural organizations, regulatory decisions, laws, administrative measures, scientific statements, philosophical, moral, philanthropic propositions" that may have the strategic function of producing truths with powerful effects on bodies, thus becoming biopolitical. Biopolitical governmentality is, therefore, this peculiar government of the bodies instituted by Western modernity - free translation from Portuguese: "[...] discursos, instituições, organizações arquitetônicas, decisões regulamentares, leis, medidas administrativas, enunciados científicos, proposições filosóficas, morais, filantrópicas." (1998, p. 244)

4 Homophobia/lesbophobia/ transphobia is understood here as the set of power effects of discriminatory speeches and acts directed at people and collectives who express non-normative or alternative sexualities and gender identities. 
"[...] main discourses that dominate the debate on homosexuality, showing the colonial roots that still cross it."5 (Rea, 2018, p. 21), not only in the African context but in the Global South ${ }^{6}$.

\section{The ero/exoticization of African bodies as part of the dark continent discourse}

From the $15^{\text {th }}$ and $16^{\text {th }}$ centuries on, culminating between the $18^{\text {th }}$ and $20^{\text {th }}$ centuries, powerful discursivities establishing truths about the bodies were developed in Europe with the institution of modern biomedical sciences and legal-moral disciplines (Foucault, 1995, 1999). The instituted knowledge contributed to legitimizing the bourgeois colonial and imperialist expansionist projects, by producing, naturalizing, and justifying the hierarchies of race, gender, and sex that, to this day, continue to compose, essentialize, and materialize, through the bodies, the metaphysics of difference (Mbembe, 2000) and the imperialist and colonial difference (Mignolo, 2011). The white and virile European bodies were established as authentic carriers of civilization, rationality, and hombrity, while the non-white bodies, mainly black Africans and Native Americans, were established as bestial, emotional, or lax bodies (although this discourse was quite ambiguous), upon which a discipline of control and domestication should fall, thereby granting the submission and/or the enslavement on "scientific" and "moral" bases.

Although submission and even slavery based on racial hierarchies predate European and Arab colonialism and imperialism (Moore, 2007; N'Diaye, 2006; Trabelsi, 2010, 2016), as do gender binarism and heteronormativity (Fausto-Sterling, 2000), we realize, based on Quijano (2000), Mgnolo (2008), and Foucault (1995, 2004b), that the biopolitical dispositives of governmentality established by European modernity created and continue to impose very singular social relations based on racial and sexual cleavages that particularize coloniality. Thus, the image is forged of the nègre-biologique-sexuel-sensuel-et-génital', in Fanon's words (1952: 163), which would guarantee the sexualization and eroticization of Africa (Sub-Saharan Africa, but not only) as an instrument of power in the service of colonization (McClintok, 1995). With decolonization, sexuality and the control of bodies, as well as the medical-scientific and legal-moral discursivities of European inspiration, did not cease to be instruments of power. However, they have acquired other meanings, for example through the continuity of male domination and the silencing of certain sexual practices and alternative modes of sexual subjectivation (Amadiume, 2006; Ndjio, 2012; Nyanzi, 2011).

European medical-scientific discursivities have expanded around the world as the main institutionalized providers of truths about bodies, largely based on the elaboration of racial and sexual taxonomies (white vs. black; heterosexual vs. homosexual, etc.). Over time, the contents of the discursivities may even have undergone revisions and thus the old taxonomies have been officially rejected (or re-signified?). But their real effects are still felt today - not only populating imaginaries but also serving as parameters for policies. In the context of French colonization $^{8}$, Peiretti-Courtis (2015) analyzed the way these discursivities were
5 Free translation from Portuguese: “[...] principais discursos que dominam o debate sobre a homossexualidade, mostrando as raízes coloniais que, ainda, o atravessam."

6 It will not be presented here the discussion that gives rise to the expressions Global North and Global South. For the purposes of this article, the Global North is considered to be the set of globalizing countries in their actions of perpetuating colonialism and imperialism through capitalism, while the Global South is formed by countries and regions that react, in some way, to the impositions of the Global North, sometimes creatively producing new particular political forms and guiding global alternatives against universalism. See, to this subject, Ballestrin (2017), Castro-Gómez (2019) and Santos (2007). Nor will the discussion of the opposition between West and East be presented further here, although these categories will be used throughout the text, more or less as treated by Carrier (2003) and Said (1990).

Free translation from French, that means negro-biological-sexual-sexy-and-genital.

8 See Burton (1999), Han et al. (2018), and Levine (2007) for the British colonial context. 
inscribed in medical manuals and treatises that disseminated those taxonomies in the form of a "somatic ethnology" or a "natural history of races" and even "hygienic guides" for travelers. Through these discursivities, the invention of races and their hierarchy went hand in hand with the naturalization of the teleological reality of sexual dimorphism and gender binarism and with the imperatives of "healthy" reproduction (Gontijo, 2018; Gontijo and Schaan, 2017) that support(ed) the prerogatives of coloniality, as confirmed by Dorlin $(2006,2009)$ and Gargallo (2014). Therefore, the dark continent discourse (Jungar and Oinas, 2004) was universalized and essentialized, based on the hyper-sexualization of African bodies (Boëtsch and Savarese, 1999).

The case of Sarah Baartman illustrates well the hyper-sexualization of African bodies. This was the name given at the end of the 18th century by the colonizers to a Khoikhoi woman, an ethnic group pejoratively called "Hottentot". She was taken from her village to Cape Town, South Africa, then under English rule, to work in private homes and ranches under slave-like conditions. In 1810, a British military surgeon, Alexander Dunlop, proposed to Sarah's “employer”, Hendrik Caesars, that they could earn money by exhibiting her in freak shows in London. She caught the attention of Europeans for her hypertrophic buttocks (steatopygia) and her stretched vaginal lips (macronymphia), both organs considered more prominent than those of European women. From her exhibition between 1810 and 1814, as an animal inside a cage in London's showrooms, she was ironically nicknamed by journalists as the "Hottentot Venus", a term that would later consecrate her in sensationalist anthropological literature. After a brief stay in the Netherlands, she was exhibited in Paris from 1814 onwards by an exotic animal dealer who charged so that people could touch her. She was frequently raped and even gave birth to a child that did not survive. Some "scientists" of the time, the same who would become known for their racial and sexual taxonomies, rushed to analyze her, some with permission to carry out experiments on her body, such as Georges Cuvier. It was after contact with Sarah that Cuvier and others designated the black African populations as the "most inferior races" in existence - for some of these members of the French nobility, Sarah represented a sort of missing link between animality and humanity.

After she died in 1815, of cause never ascertained or reported, Sarah became even more of a literal object of racial(ist) speculation. Her corpse was dissected, the vulva, anus, and brain were stored in formalin solutions for research (and eventually exhibited as curious museum pieces), the skeleton was reconstructed by Cuvier and permanently exhibited until 1974 along with a life-size plaster statue. Her remains were exhibited initially at the Muséum National d'Histoire Naturelle / Jardin des Plantes, and then at the Musée de l'Homme, both in Paris, where her statue was displayed at the entrance with her back to the visitors so that they would be immediately impacted by what made Sarah so bizarre and animalistic by European racial standards: her buttocks. Shortly after the end of the apartheid in South Africa, the Khoikhoi began a popular mobilization to reinforce the request, initiated in the 1940s, for the restitution by the French government 
of Sarah's remains, which eventually happened in 2002, not without controversy. A funerary ritual was then performed in the Cape Town region to accommodate the remains - however, the brain, anus, and vulva were reportedly lost (!!) in the French museum reserves (Abrahams, 2003; Bancel et al., 2014; Blanckaert, 2014; Dias and Belizze, 2020; Ferreira and Hamlin, 2010; Gordon-Chipembere, 2011; Holmes, 2009; Qureshi, 2004). Sarah's story was not an isolated case: until the 1930s, hundreds of non-European people were exhibited, almost always by force, in human zoos (such as at the Jardin d'Acclimatation in Paris), colonial exhibitions, and universal exhibitions in Europe and the United States to strengthen the ideology of white supremacy and the consequent inferiority of non-European peoples and thus sanction colonialism and imperialism, now on a supposedly "scientific base" (Bancel et al., 2002) ${ }^{9}$.

Also in France, just over two centuries after the terror inflicted on Sarah, yet another facet of the dark continent discourse would unfold, with the controversy generated around the publications in 2018 and 2019 of two books: Sexe, Race $\mathcal{E}$ Colonies: la domination des corps $d u$ XVe siècle à nos jours (Sex, Race \& Colonies: the domination of bodies from the $15^{\text {th }}$ century to today) edited by Blanchard, Bancel, Boëtsch, Taraud, and Thomas, with a foreword by Achille Mbembe, published by La Découverte in 2018; and the following year, the same group of editors, joined by Chalaye, Robles, Sharpley-Whiting, Staszak, and Yahi edited Sexualités, Identités \& Corps Colonisés (Sexualities, Identities \& Colonized Bodies), published by the French National Council for Scientific Research (Conseil National de la Recherche Scientifique, CNRS).

The first book started from the way in which sexuality, domination, and colonization entangled in European minds over the last six centuries inventing an "other" that should be controlled through the appropriation of "its" body and territory. The publication counted with the contribution of a hundred historians, anthropologists, sociologists, political scientists, literary critics, artists, etc. from different nationalities who explained the central role that sex plays in (past and persistent) colonial power relations. With the help of 1,200 illustrations, the publication attempted to bring to light visual documents that fabricated the exotic gaze and Western erotic fantasies, reflections of colonial and post-colonial racial and sexual domination. The texts helped to understand the context of production of the images, their diffusion, and reception, as well as the importance of visual history to decolonize our view and deconstruct the colonial order that had organized sexuality based on racial criteria validated even by science. The second book continued the reflections of the first one in an attempt to demonstrate that sexuality and racial hierarchies were consubstantial to the administration of the colonial enterprise and the elaboration of transnational imaginaries inventing a kind of globalized hegemonic sexuality.

Hundreds of reports, interviews, reviews, television and radio shows, and posts on social networks and blogs have created a very negative environment for the reception of these books, accused of extolling colonial violence against colonized people and their descendants, unnecessarily spectacularizing past social
9 The documentary movie by Pascal Blanchard and Bruno Victor-Pujebet deals with the human zoos - available in https://www.youtube.com/ watch?v=pysovxQbfW8. 
relations (racialized and sexualized ones), retaking grudges and resentments that would have already been well resolved between ex-colonizers and ex-colonized people, and, finally, of being pornographic manifestos that perpetuate the sexual crimes they were intended to denounce (due to the voyeuristic character that supposedly did not consider the victims) ${ }^{10}$.

Behind the virulence of the criticisms coming from all spectrums of the political gradient was the fear of touching on the subject of "colonial ideology" and its post-colonial legacies ${ }^{11}$ by exposing the social fracture that can be observed in France today (for example, when the frequent crises explode in the French urban peripheries starring black people and/or people of Muslim origin). Dangerously, this would denounce the current fragility of the cultural arbitraries that still try to sustain the cunning French (imperialist) national project. The criticism further relates to the difficulty that colonizing countries have in dealing with the fact that sexuality was not just a marginal aspect of colonization, but a fundamental part of the colonial enterprise in the past and in its unalterable neocolonial unfolding in contemporary times - under the form, for example, of a sort of bionecropolitical coloniality (Burton, 1999; Dorlin, 2009; Hyam, 1991; Levine, 2007; Lima, 2018; McClintok, 1995; Stoler, 1995, 2002) ${ }^{12}$.

The dark continent discourse thus produced and reproduced ad nauseam perpetuated the stereotyped representation of black populations as naturally lascivious and the consequent need to discipline their bodies through heteronormativity embedded in the European civilizing process (Dorlin, 2009; Epprecht, 2008a). With the decolonization of Africa, Europe was no longer so religious, heteronormativity was no longer based on the same moral principles, and female protagonism and alternative sexualities were no longer threats to the development of the world-system idealized by the West. At that moment, part of the African elites, in general, adopted the structures of the legal and political systems and the religious ideologies of European origin for the conformation of the new national states of the continent, as observed by Kaoma (2009) and Ndjio (2012), which led to severe criticism by Western countries, now in the name of Human Rights (Aderinto, 2014; Aldrich, 2003). Internally, reactions and creative forms of resistance intensified in several African countries (Broqua, 2012; Duranti, 2008; Gaudio, 2009; Hayes, 2000; Matebeni, 2011), contrary to both Western discursivities instituting a new hegemonic order (civilizational, salvationist, and redemptionist) that seeks to reinforce the single history denounced by Adichie (2019), as well as to nationalist narratives of a sexist and/or homophobic nature that deny sexual and gender diversity in Africa and install what Herdt (2009) has called sexual panic as a modality of moral panic (Aarmo, 1999; Awondo, 2012; Awondo et al., 2013; Dudink, 2013; Guebeguo, 2006b; Gunkel, 2013; Ireland, 2013; Izugbara, 2004; M’Baye, 2013; Tamale, 2007).

\section{African Sexual and Gender Diversity in Texts, Pretexts, and Contexts}

The changes in perspectives that occurred in the European colonizing countries and in the United States from the mid- $20^{\text {th }}$ century on, represented by the
10 See some of those negative comments in:https://www. liberation.fr/debats/2018/09/30/ un-ouvrage-sans-ambition-scientifique_1682245, https:// orientxxi.info/lu-vu-entendu/ sexe-race-et-colonies-le-livrecorps-souille,2760 and https:// www.arretsurimages.net/chroniques/le-matinaute/sexe-raceet-colonies-pascal-blanchardne-veut-pas-debattre.

11 Blanchard's scholarly project involves, from its beginning, the unveiling of the contemporary dispositives that maintain what he calls "colonial ideology" and "colonial memory"" challenging the old conception of French citizenship (Blanchard, 2005). It is worth remembering that France is a colonialist nation that preserves a dozen overseas territories and departments today.

12 Critical theoretical, methodological, and epistemological perspectives grouped under the appellation of "postcolonial” (Loomba et al., 2005), in particular those organized around Indian subaltern studies (Chakrabarty, 2002), African/ Black decoloniality or pan-African critique (Malomalo, 2019; Mbembe, 2005), and Latin American decoloniality (Lander, 2005; Maldonado-Torres, 2018) seem to generate a certain discomfort in European academia, as can be noted in Amselle's (2008) deprecations. 
condemnation of raci(al)ist and eugenic practices and the gradual revision of the conceptions of gender and sexuality, as well as by decolonization itself, did not occur naturally by the initiative of the rulers of these countries, nor only as the result of struggles of the oppressed and/or colonized collectives. They were the result, above all, of reactions to the generalized discontent with the oppressive world order, which led, for example, to the creation of the United Nations and its instances and the universalization of the Human Rights message.

However, this would not have resulted in a world-system without oppressions, but rather, a displacement or resizing of power relations (Dudink, 2013). These relations, based on Western legal-moral disciplines, the ideal of social justice, and Human Rights discourses oppose what Jaunait et al. have defined as the hegemony of heterocentric nationalisms and white supremacists and thus promote the rhetoric of universal sexual democracy that reinforces the impression of a hegemonic globalized sexuality (Jaunait et al., 2013). According to Jackson (2009), Jews and homosexuals, for example, were previously considered as "races" to be banned, they have now become components of the allegedly inclusive Western cultural diversity. In contrast, Muslims, regarded as fundamentalists, and Africans, considered as traditionalists, became dangerous, no longer on biological grounds (the racial hierarchy), but on cultural grounds ("the clash of civilizations"), for allegedly disrespecting Human Rights.

The publications of the last three decades on sexual and gender diversity in the African continent seem to emerge, in the contexts described above, precisely to account for the reactions and creative forms of resistance that abound in the most diverse African countries as alternative ways of dealing with the new world-system configurations against the dark continent discourse and the single history. Before proceeding with the brief exposition of a selection of these publications, it is necessary to make some considerations.

African heterogeneity is considerable, be it cultural, political, economic, historical, or about the ways of production of scientific and philosophical knowledge, which could make any attempt to analyze together and compare this production difficult. However, since decolonization, a successful effort has been made to elaborate theoretical (and epistemopolitical) perspectives that enable transnational comparisons at the continental level (Mafeje, 2001; Mbembe, 2000; Malomalo, 2019; Mudimbe, 2013), as it is the case, for example, of the discussions promoted within the scope of the Council for the Development of Social Science Research in Africa (CODESRIA) ${ }^{13}$. In presenting the publications on sexual and gender diversity in Africa, I will not specifically discuss issues concerning how these pan-African or Afro-centric theoretical perspectives are constituted ${ }^{14}$.

Recent publications on sexualities on the continent are mostly in English, particularly edited books. They represent much more the sub-Saharan English-speaking countries, especially South Africa (and then Cameroon, Ghana, Kenya, Malawi, Nigeria, Tanzania, Uganda, and Zimbabwe), although some of these publications also discuss the realities of French- or Arabic-speaking countries - and to a lesser extent, Portuguese-speaking ones. Some journal dossiers and articles in French
13 CODESRIA, based in Dakar, Senegal, was the first institution created after decolonization to bring together African researchers and promote research in the social sciences, with a prominent role in the proposal of theories most appropriate to the multiple realities of the continent, contributing significantly to the social development of / in the region. Gender is a highly visible theme in research promoted by CODESRIA, while research on sexuality is still timid (when not directly linked to gender). See: https://www.codesria.org.

14 In addition to CODESRIA, there are a number of research and/or activist institutions that promote important discussions and studies on gender and sexuality on the continent, such as the Human Sciences Research Council (http://www.hsrc.ac.za/ en), based in South Africa, the African Regional Sexuality Resource Center (http://www. arsrc.org), based in Nigeria, the Gays and Lesbians of Zimbabwe (https://galz.org) based in Zimbabwe, or the collective Femmes Sous Lois Musulmanes (http://www.wluml.org/ $\mathrm{fr})$, with a strong emphasis on discussions and studies on reproductive health and confronting sexual diseases and violence. To enable a reflection on Afrocentrist homophobic discourses, see Gilroy (2001) or Bussotti and Tembe (2014). 
generally deal with the realities of French- or Arabic-speaking countries, most frequently Senegal, Cameroon, Ivory Coast, and Morocco, while articles, dissertations, and theses in Portuguese deal with the realities of Portuguese-speaking countries, mainly Mozambique and, to a lesser extent, Cape Verde - no Portuguese-language books or dossiers were found. The realities in the north of the continent, in Arabic-speaking countries, are often studied in comparison to the realities in the Middle East, due to the Arab-Muslim influence, and, for this reason, will be less addressed here. Nor will the Portuguese language texts be analyzed, for the reasons stated above ${ }^{15}$.

More or less insidiously, the colonial anthropological literature presents some examples of practices and identities linked to sexuality in the most diverse societies subjected to colonization. Starting from conceptions, concerns, and anxieties of the anthropologist's own society, from a functional-structuralist perspective, the researches dealt with these practices and identities by linking them coyly to the following themes: the need for marriages due to the lack of women or lack of men in the societies in question, the rituals, and transitory magical-religious activities, and the social conditions created by the colonizers, such as homosociality promoted by the labor situation in the mines of the southern part of the continent or in cities ${ }^{16}$. Indeed, according to Epprecht (2008b), homosexuality (the term Epprecht uses to address sexual and gender diversity) was almost always portrayed as an imitation of heterosexuality or something that informed about the normality/ normativity of heterosexuality; when more modern forms of sexual subjectivation began to develop in African cities, as a consequence of the economic dynamics of urbanization from the beginning of the $20^{\text {th }}$ century, anthropologists turned a blind eye, since this reality did not correspond to their functional-structuralist schemes based preferentially on the search for ethnic determinations (Epprecht, 2005).

The accounts contained in these early researches, some of them reviewed today by African researchers, served two purposes. On the one hand, they helped to demonstrate the complex relations established in the colonial period with the systematic silencing of sexual and gender diversity and its framing in Western heteronormative parameters, also showing the historical tradition of this diversity on the continent (Epprecht, 2005; Murray and Roscoe, 1998). But on the other hand, these researches reinforced, in the postcolonial period of African nation-state formation, what Epprecht (2008a) has called the nationalist allegory of exclusive heterosexuality, that is, the political use of the idea of the exogeny of homosexuality and the promotion of the alleged "naturally" African heterosexuality (Amory, 1997; Guebeguo, 2006b; Hayes, 2000; Mbembe, 2006; Mbisi, 2011; Miescher, 2005; Ndjio, 2012; Ratele, 2008; Rebucini, 2013) ${ }^{17}$.

From then on, a new generation of African researchers, mainly from the southern part of the continent, felt challenged to confront homophobic allegories and heterosexist and androcentric representations of African identity by exposing their own (or their interlocutors') "coming out" stories, according to Epprecht (2008b: 62), and to "[...] courageously seek evidence of the diversity of sensual
15 There is a good review of available texts on sexualities in the Portuguese language in Miguel's $(2014,2019)$ Master dissertation (about Cape Verde) and doctoral thesis (about Mozambique), as well as in some of his articles (Miguel, 2016a, 2016b). It is noted the scarcity of studies on the theme in São Tomé and Príncipe, Guinea-Bissau, and Angola. Some dossiers published in Brazilian journals also contain articles on the theme, not only concerning Portuguese-speaking countries, but also English-speaking countries, especially South Africa, such as the dossier published in Revista Estudos Feministas in 2019, edited by Moutinho (2019). Finally, Rea's work has been contributing in recent years to instigate reflections on sexualities in African contexts (Rea, 2017, 2019), as does Langa's article (2018).

16 For a review of the bibliography on that theme, see Epprecht (2008b), Guebeguo (2006b), Krouse (1993), Miguel (2019), Murray and Roscoe (1998), and Ombolo (1990). 17 There are many examples of politicians and even African presidents who, in recent years, have been busily denouncing the exogenous character of homosexuality on the continent and claiming that same-sex practices are also contrary to the moral precepts of the new African societies, based on Christianity (which, paradoxically, is actually exogenous to the continent). These discourses happen, in general, as reactions to the increasing visibilization of identities based on sexuality - see, for the analysis of these political discourses and their effects, Aarmo (1999), Awondo (2012), Awondo et al. (2013), Cheney (2012), Demange (2012), Guébeguo (2006a), Ireland (2013), Izugbara (2004), Larmarange et al. (2009), M'Baye (2013), Miguel (2019) and Spronk (2012). See, on a curious case in Gabon, Paola Audrey's commentary at: https://www.youtube. com/watch?v=9eUyzUFqpmc. 
desire among Africans, just as there may [be evidence of such diversity] among people of any other group in the world" - such as Achmat (1993), Donham (1998), GALZ (1995), Krouse (1993), Nkoli (1994), Mburu (2000), among others. Between the 1990s and 2010s, numerous texts coming from this critical and reflexive perspective were published, putting at risk those allegories and the representation of African hyper-heterosexualization and denouncing the limitations of the categories "homosexual", "bisexual" and "heterosexual" for understanding regional realities, such as, in chronological order of release, the books edited by Gevisser and Cameron (1995), Murray and Roscoe (1998), Blackwood and Wieringa (1999) ${ }^{18}$, Arnfred (2004), Morgan and Wieringa (2005), Cole et al. (2007), Reddy et al. (2009) ${ }^{19}$, Tamale (2011), Diesel (2011), Nyeck and Epprecht (2013), Ekine and Abbas (2013), Martin and Makhosazana (2013), Matebeni (2014), Sandfort et al. (2015), Lachheb (2016), Matebeni (2018) and Spronk and Hendriks (2020) and the dossiers edited by Broqua (2012), Broqua et al. (2009), Epprecht (2009) and Guebeguo (2009), Blidon and Roux (2011), and Sandfort and Reddy (2013), and the books authored by Hayes (2000), Hoad (2007), Epprecht (2008a, 2008b, 2013), Gaudio (2009), Kaoma (2009), and Gunkel $(2010)^{20}$, among others.

In $1995^{21}$, the pioneering book edited by Gevisser and Cameron was published, dealing specifically with the South African context at a very troubled time in the country $^{22}$. Undoubtedly, the book edited and published in 1998 by Murray and Roscoe is the first book most often cited when it comes to research on expressions of sexual and gender diversity in various African contexts, and probably the one that directly or indirectly served as inspiration for the development of subsequent research ${ }^{23}$. The two American sociologists/anthropologists/activists - who played a relevant role in the compilation of dozens of texts on alternative sexualities in the most diverse places on the planet - brought together in this book entitled Boy-Wives and Female-Husbands: Studies in African Homosexualities ${ }^{24}$ a set of more than 20 texts, comprising academic articles, colonial memoirs, and contemporary accounts, including those authored by African researchers, in an attempt to first question the myth of the foreign origins of homosexuality in Africa and thus to instigate research that would account for the multiplicity of African social situations and "patterns of same-sex sexuality" (1998: xviii). For the editors, the "myth" of the denial of African sexual and gender diversity spread by Europeans became a "taboo" spread by Africans in the post-colonial period but based on a European morality. And they state:

The colonialists did not introduce homosexuality to Africa. Instead, the Europeans introduced intolerance of homosexuality - and systems of surveillance and regulation for suppressing it. These systems failed as long as the African reaction was to hide or deny such practices. Only when native people began to forget that same-sex patterns were ever a part of their culture did homosexuality become truly stigmatized. (Murray e Roscoe, 1998, p. xvi)

From the message above given by Murray and Roscoe and reinforced by the
18 The book edited by Blackwood and Wieringa (1999) deals, in its thirteen chapters, with women's experiences of non-normative sexualities around the world and presents two fundamental texts for research in African contexts: Kendall's chapter addresses traditional relations between women in Lesotho and the current impact of the construction of Western lesbophobic discourses (the author also had a chapter on the same subject in the book by Murray and Roscoe, 1998), while Aarmo's text shows the way women deal with the idea of the exogeny of homosexuality in Zimbabwe.

19 This is a book about AIDS policies in the South African context, with some chapters resulting from comparative research conducted in other English-speaking countries such as Malawi and Zimbabwe.

20 The author deals with the way sexual identity emerged in the post-apartheid national discourse in South Africa, making the country the first on the continent to recognize the rights of homosexual people in the 1990s. However, she shows that this does not mean that there is wide acceptance of non-normative sexualities in the country, due to the persistence of the idea of the exogeny of homosexuality and the prevailing modalities of nationalist discourses.

21 There is also an edition by Ravan Publishing, Johannesburg, dated 1994.

22 There are a large number of texts on sexual and gender diversity in South Africa that will not be commented on here as they would make a separate article, such as Currier (2012), Matebeni (2011), Read (2013) or Tucker (2009).

23 Recently, in honor of the book's 20th anniversary, an article was published addressing some important contributions of the work to sexuality studies in Africa (Epprecht, Murray, Andam, Miguel, Mbaye \& Gaudio, 2018).

24 The title seems to dialogue directly with Amadiume's (1987) 
other authors of the book, African production on the subject increased consistently throughout the 2000s. At the beginning of the decade, Hayes' book (2000) entitled Queer Nations: Marginal Sexualities in the Maghreb was published. It addresses the gender insubordination, dissident sexualities, and marginal sexual experiences portrayed in literary works that went against the nation-building projects in force in Morocco, Algeria, and Tunisia, former French possessions. The writers cited by Hayes envisioned an anti-colonial struggle that would result in sexual liberation and more inclusive nations, which ultimately did not happen. This book, along with Rebucini's work $(2009,2013)$ on Morocco and the book edited by Lachheb (2016) containing twelve chapters on the three Maghreb countries and the North African diaspora in France, dialogue much more with other publications that address sexual and gender diversity in Islamic countries and the homo-islamicus (Lachheb, 2016) beyond Africa - such as, the texts contained in Schmitt and Sofer (2013 [1992]) or in Murray and Roscoe (1997) or even Massad's book (2007) - than with writings analyzing regions of Islamic majority in sub-Saharan Africa - such as, Gaudio (1998, 2009), Larmarange et al. (2009), M’Baye (2013), Niang et al. (2002) or Teunis (2001). While the former attest more vigorously to the impact of the religious marker and the effects of Arab-Muslim and European colonizations on sexualized practices and identities, the latter point to the relevance of religiosity in its relation to ethnicity, "African tradition", and the effects of European colonization. This is the particularity of the writings on sexual and gender diversity in Muslim-majority contexts on the continent.

In 2004, Re-Thinking Sexualities in Africa was published and edited by Arnfred. Along its twelve chapters, it addresses mainly female sexuality in the most diverse African national contexts. It starts from the critique of the way African sexualities are socially constructed as "others" in relation to European modernity, rationality, and civility. While the first part contains texts that theoretically question the production of the dark continent discourse, the second part presents research on desires carried out in some areas of the continent invisibilized by mainstream researchers. Finally, the last part addresses the ongoing socioeconomic changes that are directly affecting gender relations and sexualities.

The book edited in 2007 by Cole et al. under the title Africa after Gender? also proposes reflections on the relations between gender and sexuality based on that alleged African "otherness". The sixteen texts in the book address the following themes: the volatility of the concept of gender when applied to the African continent and the very volatility of gender itself with the emergence of new models of women, public spaces and female activism, the relations between gendered subjectivations and the elaborations of national identities, and finally masculinities, misogyny, and seniority in the so-called "post-gender" African context. In these two books, one can perceive the joint path traced by gender studies and sexuality studies on the continent.

Since 2005, several publications show a more direct approach of non-normative and alternative sexualities, such as Tommy Boys, Lesbian Men and Ancestral Wives, edited by Morgan and Wieringa, about the dissident sexual and gender also groundbreaking book, Male Daughters, Female Husbands: Gender and Sex in an African Society, which deals with how women in a particular rural region of Nigeria had their status of power transformed by colonialism and religion and maintained by the educational system; the author suggests that Third-World women must politically challenge governments by denouncing the cultural and historical arbitraries that underpin patriarchal systems in order to regain the power they had before colonization, now on new bases. The author's texts (see also Amadiume, 1997) echo those of Oyěwùmí (1997) in proposing an African feminist thought critical of Western black and white feminisms. 
identities and practices of women. This peculiar book, that is originated in an activity of the congress of the International Association for the Study of Sexuality, Culture and Society (IASSCS), brings together ten texts written by women who, in their respective countries (South Africa, Namibia, Kenya, Swaziland, Tanzania, Uganda, and Zimbabwe), are either human rights and "homosexual" activists or social workers and researchers. They were asked to collect narratives about homophobic practices and the tactics adopted by the interlocutors to maintain the "secrecy" and the "silence" for survival in a hostile environment - Miguel (2016a, 2019) observed similar tactics in his research with men in Mozambique and Cape Verde. Therefore, the book shows forms of traditional and institutionalized relationships among women in some areas of the continent, their claims for sexual rights, and the emotions of those who resist oppression in their communities.

The book by Hoad (2007) - entitled African Intimacies: Race, Homosexuality, and Globalization - and the two books by Epprecht (2008a, 2008b) - the first one entitled Heterosexual Africa? The History of an Idea from the Age of Explorations to the Age of AIDS and the second one, Unspoken Facts: A History of Homosexualities in Africa are important due to the historicities and critical theories they offer.

Hoad starts from the speeches given by African political leaders on the "exogeny of homosexuality" to propose a critical analysis of the anthropological production, covering the genealogies of the exaggerated representations of African "homosexuality" (and of the ideas of race, sex, and nation) in the context of the historical experiences of imperialism, decolonization, and globalization. He denounces several problems inherent in the texts produced on the subject: the definition or lack of definition of what is meant by "Africa", the designation of what is defined as "sexuality" as an analytical category or as "sexualities" as a classificatory category, and the delimitation of "homosexuality" or "homosexualities". These issues are present in the texts in Murray and Roscoe (1998) and in Arnfred (2004) or even in the work of Amadiume (1987) - considered, however, positively as pioneering. Hoad assesses the public character that sexuality seems to acquire "naturally" in modern Western thought - the embodied pleasures, their histories, and traumas, as already stated by Foucault (1999) -, which seems to contrast with the expressions of sexual and gender diversity in Africa, marked by "secrecy" and "silence" - as also suggested by Miguel (2019) and Morgan and Wieringa (2005). Finally, the author presents a study of historical and literary representations of intimacies between men. He contextualizes them in light of recent debates about the "exogenous character of homosexuality" and the need to discuss sexuality in Africa about the HIV/AIDS epidemic on the continent.

As for Epprecht's books (2008a, 2008b), both denounce the heterosexist character of $19^{\text {th }}$ and $20^{\text {th }}$ centuries ethnographic production that made sub-Saharan Africa the place par excellence of the denial of homosexuality by creating "[...] the impression that Africans are practically unique in the world by the absence of, ignorance about, or intolerance toward exceptions to heterosexual norms." (2008a, p. 35). During the colonial era, Europe condemned homosexuality while its practice was commonplace in certain situations on the African continent. When 
Europe began to promote the discourse of Human Rights, including that of homosexual people, Africa was accused of disrespecting Human Rights and, in particular, the sexualities considered by Europeans as non-normative, since the continent continued to occupy the privileged place of absolute otherness and exception in relation to Europe. Recently, according to the author, researchers informed by post-structuralism, feminist critique, and queer theory, after the (partial) decriminalization and destigmatization of homosexuality in laws, psychiatry, and popular culture in the West, have endeavored to counter the stereotypes produced over the centuries. New researches on the experiences of sexual and gender diversity in ritual and magical-religious contexts, in parallel with the emergence of Western-inspired, openly "homosexual" urban activist groups opposed to state and religious homophobia, challenge the traditional culture of "secrecy" and "silence". The Western partners of these activists and agents in the new urban scenario make use of, in part, colonial anthropological studies to justify "homosexuality" as something naturally African, but, according to Epprecht, without much criticism of this already dated and markedly colonialist researches ${ }^{25}$.

The protagonism of Epprecht's enterprise is further noted in the organization, in 2009, of the dossier "New Perspectives on Sexualities in Africa", together with Guebeguo, published in the Canadian Journal of African Studies. This dossier contains articles and reviews in English and French on widowhood and inheritance in Uganda, religion and AIDS prevention in Namibia, transactional sexualities among men in Mali, homosexual activism, disability, and AIDS in South Africa, sexual morality and corporeality in Kenya, and finally, activism and gay rights in Cameroon. The two introductory texts by the editors (Epprecht, 2009; Guebeguo, 2009) together constitute a review of new perspectives on research on the continent.

In the same year, the dossier "La Fabrique des Identités Sexuelles" (The Factory of Sexual Identities) was also published in the journal Autrepart, edited by Broqua and Eboko (2009). It presents articles resulting from researches in various contexts around the world, including in African countries, in particular on the religious framing of sexual practices in Ethiopia, the perceptions of wives of men who have sexual relations with other men in Senegal, commercialized sexual transactions in a tourist area in the same country, commercialized sexual transactions of women in Morocco, the social conception of virility in Burkina Faso, monetized marital relations in the same country, male and female identities in times of globalization in Mali, and finally "transactional sexualities" in an urban area in Cameroon.

Broqua edited another dossier in 2012 on African contexts, in the journal Politique Africaine (“L’Émergence des Minorités Sexuelles dans l'Espace Public en Afrique", The emergence of sexual minorities in the public space in Africa). This dossier contains articles on the role of United States evangelical Christians in shaping sexual morality and the political agenda in Uganda, heterosexism in rap music in Gabon, media, politics, and homosexuality in Cameroon, the insertion of the category "transgender" in activism in Namibia and South Africa, an art exhibition on transgenderity and social justice on the continent, a photo essay, and
25 It is worth mentioning the importance of Kaoma's work, with several texts published since 2009 dealing with the relationship between religiosity and sexuality, with emphasis on the effects of the advances of United States neo-Pentecostal Christian churches, especially in the context of Uganda (Kaoma, 2009). 
a French translation of part of Evans-Pritchard's classic "Sexual Inversion among the Azande", originally published in the early 1970s.

Two other dossiers were published. The first one is very succinct, in French, "(Géo)politique du Sexe" (Geopolitics of sex) and was edited by Blidon and Roux (2011) and published in the journal L'Espace Politique. It is composed of articles on male homosexuality and on the relationship between labor migration and sexuality, both in Morocco and one on "homosexual identifications" and post-colonial tensions in Cameroon, in addition to articles on sexuality among African migrants in France. The second one, in English, "African Same-Sex Sexualities and Gender-Diversity", was edited by Sandfort and Reddy (2013) and published in the journal Culture, Health \& Sexuality. It contains eight articles and seven reviews; the articles are based on case studies conducted in English-speaking countries, such as South Africa, Botswana, Cameroon, Ghana, and Nigeria.

In the 2010s, the literature seems to bring some kind of affiliation to the queer theory more explicitly - always taking into account local theoretical needs. This was the case, for example, of Queer African Reader, published in 2013 and edited by Ekine and Abbas. The book was translated into Portuguese, reorganized, and recently published in two parts - the first one by Rea, Paradis, and Amancio (2018) and the second one by Rea, Fonseca, and Silva $(2020)^{26}$. In the second publication in Portuguese, besides chapters from the Queer African Reader, one can also find some translated chapters from another important book published in 2014 and edited by Matebeni, Reclaiming Afrikan: Queer Perspectives on Sexual and Gender Identities. The book by Matebeni brings together not only academic texts but also critical and artistic essays. Both books aim to recover the anti-normative character of queer theory and associate it with a reflection on African identity from an anti-colonial perspective - hence the title of the second book - and the need to produce knowledge by connecting academic production and arts to activism. In 2018, Matebeni edited another book with Moro and Reddy, continuing their project, Queer in Africa: LGBTQI Identities, Citizenship, and Activism, with texts by researchers and activists from English-speaking countries on the continent, mainly South Africa.

Still in the 2010s, Tamale edited African Sexualities: a Reader, published in 2011, Nyeck and Epprecht edited Sexual Diversity in Africa: Politics, Theory, Citizenship, of 2013, Sandfort, Simenel, Mwachiro, and Reddy published Boldly Queer: African Perspectives on Same-Sex Sexuality and Gender Diversity, 2015, and Epprecht wrote Sexuality and Social Justice in Africa, 201327.

The first one, with almost 700 pages and more than 60 chapters by authors from countries all over the continent, joins theoretical reflections and academic discussions with poems, essays, and activist texts. The book begins with reflections related to the particularities of research on sexual and gender diversity on the continent and the discussion of particular theories, goes through a wide range of topics (power and politics of sexuality, sexual representations and identity practices, reproductive rights, masculinities, physical disability and vulnerability, AIDS, violence and homophobia, and spirituality) and ends with the proposal of
26 For more detailed comments on the book, see Rea's publications $(2017,2019)$.
27 Also worth mentioning are the less academic books edited by Diesel (2011) - which brings together biographical narratives, poems, photo essays, and accounts of the South African lesbian universe - and the one by Martin and Makhosazana (2013) -which contains literary short stories depicting the experiences of non-normative and alternative sexualities in various African contexts. 
"pedagogical approaches" to counter the perception that non-normative sexualities are exogenous and not consistent with contemporary African reality. The book edited by Sandfort et al. (2015), as a result of a congress that took place in Nairobi in 2014, aligned with the undertakings of Tamale (2011), Ekine and Abbas (2013) and Matebeni (2014), and Matebeni et al. (2018), compiles texts, papers abstracts, and photo essays by academics and activists from diverse areas of Africa (mainly, English-speaking countries, such as South Africa, Botswana, Nigeria, Kenya, and Uganda), largely who consider themselves as queers, gays, lesbians, homosexuals, etc.

The book edited by Nyeck and Epprecht (2013), on the other hand, has just over ten chapters with the results of researches - conducted in Cameroon, Gambia, Ghana, Mali with special emphasis on South Africa - around the need to decolonize Western representations in order to understand " $[. .$.$] the complex,$ multifaceted nature of sexuality, sexual practices, and gender performance in Africa." (Nyeck and Epprecht, 2013, p. 5). Moreover, the book dated the same year exclusively authored by Epprecht presents another good review of studies on sexuality in the continent, an important discussion on the relations between state, churches, and sexuality, and a propositional reflection with the strategies for the struggles for social justice. The four main arguments supported by the author are: non-normative sexualities are not exogenous to the continent; the ordinary "secrets" and "silences" about sexual and affective experiences can be revealed and traditions can be modified without the "African civilization" perishing; Human

Rights for "sexual minorities" can benefit the entire population; and the excessive focus on negative aspects of African ways of life (on the part, but not only, of international organizations that globalize the fight against homophobia without taking into account local particularities) harms, rather than contributes to local demands for rights and justice.

Epprecht (2013) proposes to talk more about social justice rather than rights, because the idea of rights suggests litigation, protest, state, and political economy, while the idea of justice suggests negotiation, education, and the role of culture in validating inequality. He proposes that we speak of erotic justice, building on Ellison (1996) and Kapur (2005), rather than sexual rights or sexual justice, because "[...] historical privileges by class, race, and gender have not only been built into the capitalist political economy over hundreds of years of unequal globalization, they are now very densely built into cultural notions about what is and is not sexy." (Epprecht, 2013, p. 34). Based on the African context and how sexualities appear centrally in political debates, Epprecht further suggests, following Ellison's proposal (1996, p. 114), a liberating ethics of sexuality as the basis for the necessary erotic justice that contributes to the abolition of the oppressive power effects produced by the biopolitical dispositives of governmentality in force on the continent in association with Western injunctions.

More recently, a last book was published in English, edited by Spronk and Hendriks (2020), containing 24 texts divided into six parts (representations of African sexualities; biopolitics and sexual health; gendered identities and same-sex 
sexual practices; transactional sexualities; religiosity and tradition; and agency and pleasure). The book features results of recent researches conducted in different areas of the continent (both English- and French-speaking), but also some previously published texts by anthropologists considered to be "classics", such as Evans-Pritchard and Herskovits.

In summary, the 1990s presented a bibliographic production based mainly on personal accounts of the experiences of sexual and gender diversity of African people who decided to pedagogically describe their "coming out", while the 2000s reinforced the proposal presented in the book by Murray and Roscoe (1998) to produce critical reflections on the supposed exogeny of homosexuality and on the alleged "natural" homophobia in/of the continent. The 2010s were marked by the adaptation of some issues of queer theory to African historical, social, and cultural particularities, by the development of more transnational approaches and, finally, by the elaboration of a perspective that can be defined as African/Black decoloniality (Malomalo, 2019) or postcolonial queer (Rea, 2017).

\section{Perspectives}

After all, what lessons can be learned from African studies on the experiences of sexual and gender diversity to help understanding other realities? These lessons can be inferred directly from what the studies, to a greater or lesser extent, have in common: 1) the questioning character about the formation and configuration of states and national projects; 2) the critical attitude towards international organizations and institutions for the defense and promotion of Human Rights and their actions on the continent; and 3) as a corollary, on the one hand, the need to produce reflections on local particularities in their connections with nation-building ideologies (and the biopolitical structuring of governmentality), and on the other hand, the production of these reflections in their connections with the international context of the so-called global culture wars (Kaoma, 2009; Sandfort et al., 2015).

Balibar (1988) suggests that modern national states are products of colonization since they were all colonized or colonizers in some way, or both at the same time. This type of state became universal with European expansionism between the $16^{\text {th }}$ and $20^{\text {th }}$ centuries, based, as showed by Quijano (2000) and Wallerstein (2006), on colonial, imperial, and capitalist exploitation of a majority by a minority, through bio(necro)political control of the bodies through regimes of truth that establish racial ideology and hierarchy, gender binarism and heteronormativity, among other dispositives supported by and sustaining Western medical-scientific and legal-moral discursivities (Agamben, 1995; Foucault, 2004a, 2004b; Mbembe, 2018). In this way, the state relates to sexuality by elaborating the technologies of power/knowledge of governmentality that will serve to control the population and their bodies through mechanisms of security and coercion located in a territory (Foucault 2004a, 2004b).

Western national states would be considered as "civilized" for defending the 
ideal of Human Rights and individual freedoms and even managing some forms of identity-based on the experiences of sexual and gender diversity, always in the name of scientific truth and legal security. Therefore, non-Western states would be designated as "uncivilized" for keeping the population or part of it under the grip of violent security mechanisms to ensure the sovereign integrity of the national territory, often legitimizing the use of coercion in the name of religion and tradition. The former are seen as the bearers of universal happiness, while the latter are seen as "others", promoters of hatred; and thus whiteness is normalized as a "natural" expression of civilization and "true" human values (Dabashi, 2011).

The relationship between state and sexuality mediated by social control is not exclusive to the political regimes considered by Western states as oppressive, but are at the existential basis of all national states, including Western ones, which have always created some kind of homo sexualis, just as they instituted the "legitimate" homo œeconomicus, homo politicus, homo religiosus, in short, the homo nationalis... modern and Western ones. Precisely, African studies on sexuality seem to have as a mark the strong interest in the formation of this homo sexualis connected to the homo nationalis. By summarizing the works of researchers who had analyzed the relation between the state and sexuality, Puri (2004) noticed the recurrence of the theme of the control carried out by the state over the most diverse aspects of private life, when it delimitates the (variable) contours of the so-called "respectable sexualities". Because it is a Western invention, the concept of sexual identity, according to Vanita (2002), won over the world through European expansionism with particular meanings to each cultural context, due to the local configurations of power relations that define the regimes of truth, the biopolitical dispositives, and the institutional and ideological mechanisms of social control over bodies that locally determine what is "normal" and what is "abject" and that institute and reinforce inequalities of gender, class, race, etc. - in short, due to the local forms of the coloniality/imperiality of power/knowledge (Ballestrín, 2017; Gontijo, 2018a, 2018b; Quijano, 2002; Lander, 2005; Tamale, 2011).

When addressing the relations that the state establishes with silenced and oppressed people, Das and Poole (2004) propose an ethnography of the practices, places, and languages considered to be at the margins of the national state, that is, the way in which "[...] the practices and politics of life in these areas shaped the political, regulatory, and disciplinary practices that constitute, somehow, that thing we call 'state.'” (2004, p. 3). For the authors, these people were defined as "[...] excluded from, or opposed to, the forms of administrative rationality, political order, and authority consigned to the state." (2004, p. 5). The state presents itself as the locus of order and, consequently, its margins would be the place of disorder, over which would fall the force of the legitimate use of (physical and symbolic) state violence to impose the "cultural order", and thus controlling and domesticating the "state of nature" prevailing there. But, according to the authors, at the margins, the state's action may be preyed upon by the people and thus used in the service of their political and economic survival. This can be seen, for example, in the counter-cultural forms of questioning the state and of negotiation of alterna- 
tive and non-normative existences, as the African authors show very well in their texts on sexuality (Tamale, 2011).

Informed by the mechanisms that underlie the coloniality/imperiality of power/knowledge structuring colonial difference and internal colonialisms (Cardoso de Oliveira, 1993; Lander, 2005) and aware of the deprovincializing potential of doing anthropology from the standpoint of the Global South (Chakrabarty, 2007; Mafeje, 2001, 2008; Restrepo and Escobar, 2005), Brazilian anthropology and social sciences, in general, could analyze, from the margins of the state, the original forms of creative resistance to the religious, medical and legal disciplinary knowledges, discourses, practices, and powers that were naturalized and became hegemonic in Brazil. This is what our colleagues from some African countries have been doing very rigorously. Thus, anthropology and the social sciences could help to understand how the projects of governmentality instituting the national state and legitimating forms of what can be called bionecropolitical coloniality were established. They could also reinforce the consequent anti- and counter-hegemonic and decolonial reactions (Dudink, 2013; Epprecht, 2013; Jaunait et al., 2013; Tamale, 2011).

Another important mark of African studies on sexuality seems to be the (successful) attempt to produce knowledge that, even starting from national realities, can contribute to transnational comparative reflections at the continental level. With all due reservations about the heterogeneity of the continent (Hoad, 2007; Malomalo, 2019) and cautious about the dangers of the single history (Adichie, 2019) and the metaphysics of difference (Mbembe, 2000), these studies echo a joint effort to understand local realities from their insertion in a larger scope that has as its main characteristic a social and political history linked to the effects of colonialism, imperialism, and capitalism/neoliberalism that shape the world-system (Wallerstein, 2006; Woltersdoff, 2006/7). Many of these studies, for example, address the local particularities of countries, regions, or ethnic groups with regard to "sexualities", "homosexualities", or "sexual and gender identities", with these terms always in the plural, to emphasize the fact that this is a diverse and complex reality, but without failing to relate this diversity to an "African" substratum or to its location après tout in Africa. In studies on sexualities in Latin American countries, especially in Brazil, this concern in promoting transnational analyses is rarely seen and there seems to be even a suspicion in relation to the few studies that have ventured to produce comparative reflections between regional or national realities, as done by Murray (1995) or Gontijo, Arisi and Fernandes (2021).

Finally, one more element of African studies on sexuality can be highlighted here: the way they relate national configurations and continental ideals to the critique of global actions promoted by international agencies and institutions, such as non-governmental organizations and the United Nations and its various instances, usually based in Western countries. To exist as an instrument of government, which promotes happiness for some and limits it for others, the dominant groups at the head of the state need to forge a symbolic basis that accommodates their power practices so as not to be questioned, namely, a national ideology that 
attributes meanings to the state technologies of power/knowledge and biopolitical dispositives (Dudink, 2013; Jaunaitet al., 2013). Forms of homonormative nationalisms and homonationalisms come into play in some countries, that is, the way in which some Western states situationally incorporate the defense of certain dissident experiences of sexuality into their national ideology and to their needs of international expansion, to the detriment of other (local) forms of existence (Puar, 2007).

After September 11, 2001, according to Puar (2007), the United States and some European countries, in the outbreak of the "war on terrorism", used the defense of Human Rights and particularly of "homosexual" identity rights to legitimize the diffusion of an increasingly positive image of the West against Islamic peoples (Massad, 2002, 2007). These countries developed a hegemonic representational policy as a way of showing themselves as more "civilized", guardians of the primordial rights of all human beings, in relation to nations defined, therefore, as "uncivilized" that supposedly promoted terrorism and did not even respect human sexual and gender diversity. In doing so, however, according to Puar (2007), the tensions internal to each Western country related to the multiple ways of experiencing sexuality locally were totally hidden and the differentiated treatment given by the state, through biopolitical dispositives, to this multiplicity was then silenced, valuing a certain "respectable sexuality" over all other forms. In the context of the United States, the author questions the hegemonic representational politics established in association with what best suits the desires of the state, thus generating actions marked by what she calls homonationalism.

Thereafter, Western non-governmental organizations, as well as international agencies promoting economic development, fostering governance, or fighting sexually transmitted diseases, conditioned their actions aimed at regions and countries of the Global South according to the local level of respect for so-called "homosexual rights" (Jaunait et al., 2013) and in conformity to Western forms of sexual imagined community (Jackson, 2009), often disregarding (or only partially considering) local expressions of sexuality and the way they are inserted into complex national political configurations (Massad, 2002, 2007). Therefore, there is a risk of reinforcing fallacious dichotomies that arbitrarily establish "civilized" centers and "uncivilized" margins, of naturalizing the superiority of the universalist, regulatory, and homonationalist Western project over the nationalist culturalist identities of the Global South, and, ultimately, of essentializing the alleged incompatibility of modernity with "typically" Third World traditionalism. Finally, the differences between the conflicting national projects are thus transfigured into sexual differences, becoming yet another important instrument for the control of the Global South by the West at the world level, as well denounced by the African studies cited above (Epprecht, 2013; Hoad, 2007). This is yet another subject little addressed in the studies on sexuality produced in Latin America.

In conclusion, the researches conducted in African contexts, by proposing what Dorlin (2009) defines as epistemologies of resistance against globalized hegemonic sexual epistemologies, indicate clues that can be taken into account to 
Fabiano Gontijo

produce critical and reflexive knowledge capable of contributing to minimizing the perverse effects of the persistent bio(necro)political coloniality, besides contributing to the dissolution of, as suggested by Arnfred (2004) or Wieringa and Sivorí (2013), oppressive heteronormative binary systems. Here are the tips for Brazilian anthropology and the social sciences.

Recebido: 25/02/2021

Aprovado: 04/03/2021 


\section{References}

AARMO, Margrethe. How Homosexuality Became "Un-African": The case of Zimbabwe. In: BLACKWOOD, Evelyn; WIERINGA, Saskia W. (Orgs.). Female Desires. New York: Columbia University Press, 1999.

ABRAHAMS, Yvette. Colonialism, Dysfunction and Disjuncture: Sarah Bartmann's resistance (remix). Agenda: Empowering Women for Gender Equity, v. 17, n. 58, p. 12-26, 2003. Available at: https://www.tandfonline.com/doi/abs/10.1080/10130950.2003.96 74488. Access on: 5 May 2020.

ACHMAT, Zackie. "Apostles of Civilised Vices": "Immoral practices" and "unnatural vice" in South African prisons and compounds, 1890-1920. Social Dynamics, v. 19, n. 2, p. 92-110, 1993. Available at: https://www.tandfonline.com/doi/ abs/10.1080/02533959308458553. Access on: 5 May 2020.

ADERINTO, Saheed. When Sex Threatened the State: Illicit sexuality, nationalism, and politics in colonial Nigeria, 1900-1958. Champaign: University of Illinois Press, 2014.

ADICHIE, Chimamanda N. O Perigo de uma História Única. São Paulo: Companhia das Letras, 2019.

AGAMBEN, Giorgio. Homo Sacer: Sovereign Power and Bare Life. Stanford: Stanford University Press, 1995.

ALDRICH, Robert. Colonialism and Homosexuality. Londres: Routledge, 2003.

AMADIUME, Ifi. Male Daughters, Female Husbands: Gender and sex in an African society. Londres: Zed Books, 1987.

AMADIUME, Ifi. Re-Inventing Africa: Matriarchy, religion and culture. Londres: Zed Books, 1997.

AMADIUME, Ifi. Sexuality, African Religio-Cultural Traditions and Modernity: expanding the lens. CODESRIA Bulletin, n. 1-2, p. 26-28, 2006. Available at: http://www.arsrc.org/ downloads/features/ amadiume.pdf. Access on: 5 May 2020.

AMORY, Deborah P. "Homosexuality" in Africa: Issues and debates. Issue: A Journal of Opinion, v. 25, n. 1, p. 5-10, 1997. Available at: https://www.jstor.org/stable/1166238?seq=1. Access on: 5 May 2020.

AMSELLE, Jean-Loup. L'Occident Decroché: Enquête sur les postcolonialismes. Paris: Pluriel, 2008.

ARNFRED, Signe (Org.). Re-Thinking Sexualities in Africa. Upsala: Nordiska Afrikainstitutet, 2004.

AWONDO, Patrick. Médias, Politique et Homosexualité au Cameroun. Retour sur la Construction d'une Controverse. Politique Africaine, v. 126, n. 2, p. 69-85, 2012. Available at: https://www.cairn.info/revue-politique-africaine-2012-2-page-69.htm. Access on: 5 May 2020.

AWONDO, Patrick; GESCHIERE, Peter; REID, Graeme. Une Afrique Homophobe? Sur quelques trajectoires de politisations de l'homosexualité: Cameroun, Ouganda, Sénégal et Afrique du Sud. Raisons Politiques, v. 49, n. 1, p. 95-118, 2013. Available at: https://www.cairn.info/revue-raisons-politiques-2013-1-page-95.htm. Access on: 5 May 2020.

BAKARE-YUSUF, Bibi. "Yorubas Don't Do Gender”: A critical review of Oyeronke Oyewumi's The Invention of Women: Making an African sense of western gender discourse. 
Fabiano Gontijo

African Identities, v. 1, n. 1, p. 119-140, 2003.

BALIBAR, Etienne. La Forme Nation: histoire et idéologie. In: Étienne Balibar \& Immanuel Wallerstein (Orgs.). Race, Nation, Classe: les identités ambiguës. Paris: La Découverte, 1988. p. 117-143.

BALLESTRIN, Luciana. Moralidade/Colonialidade sem “Imperialidade"? O Elo Perdido do Giro Decolonial. DADOS, v. 60, n. 2, p. 505-540, 2017.

BANCEL, Nicolas; BLANCHARD, Pascal; BOËTSCH, Gilles; DEROO, Éric; LEMAIRE, Sandrine. Zoos Humains. De la Vénus Hottentote aux reality show. Paris: La Découverte, 2002.

BANCEL, Nicolas; DAVID, Homas; THOMAS, Dominic (Orgs.). The Invention of Race: Scientific and popular representations. Londres: Routledge, 2014.

BLACKWOOD, Evelyn; WIERINGA, Saskia W. (Orgs.). Female Desires. New York: Columbia University Press. 1999.

BLANCHARD, Pascal. La Fracture Coloniale. Paris: La Découverte. 2005.

BLANCHARD, Pascal; BANCEL, Nicolas; BOËTSCH, Gilles; THOMAS, Dominic; TARAUD, Christelle (Orgs.). Sexe, Race et Colonie: La domination des corps du XVe siècle à nos jours. Paris: La Découverte, 2018.

BLANCKAERT, Claude. La Vénus Hottentote entre Barnum et Muséum. Paris: Muséum National d'Histoire Naturelle, 2014.

BLIDON, Marianne; ROUX, Sébastien. L'Ordre Sexuel du Monde. L'Espace Politique, v. 13, n. 1, s/p, 2011. Available at: https://journals.openedition.org/espacepolitique/1813. Access on: 5 May 2020.

BOËTSCH, Gilles; BANCEL, Nicolas; BLANCHARD, Pascal; CHALAYE, Sylvie; ROBLES, Fanny; SHARPLEY-WHITING, Denean T.; STASZAK, Jean-François; TARAUD, Christelle; THOMAS, Dominic; YAHI, Naïma. Sexualités, Identités \& Corps Colonisés. Paris: CNRS, 2019.

BOËTSCH, Gilles; SAVARESE, Eric. Le Corps de l'Africaine. Érotisation et Inversion. Cahiers d'Études Africaines, v. 39, n. 153, p. 123-144, 1999. Available at: https://www. persee.fr/doc/cea_0008-0055_1999_num_39_153_1967. Access on: 5 May 2020.

BROQUA, Christophe. L'Émergence des Minorités Sexuelles dans l'Espace Public en Afrique. Politique Africaine, v. 126, n. 2, p. 5-23, 2012. Available at: https://www.cairn. info/revue-politique-africaine-2012-2-page-5.htm. Access on: 5 May 2020.

BROQUA, Christophe; EBOKO, Fred. La Fabrique des Identités Sexuelles. Autrepart, v. 49, n. 1, p. 3-13, 2009. Available at: https://www.cairn.info/revue-autrepart-2009-1page-3.htm. Access on: 5 May 2020.

BURTON, Antoinette (Org.). Gender, Sexuality and Colonial Modernities. Londres: Routledge, 1999.

BUSSOTTI, Luca; TEMBE, António. A Homossexualidade na Conceção Afrocentrista de Molefi Kete Asante: entre libertação e opressão. Revista Ártemis, v. 17, n. 1, p. 15-24, 2014. Available at: https://periodicos.ufpb.br/ojs/index.php/artemis/article/ view/20084/11126. Access on: 5 May 2020.

CARDOSO DE OLIVEIRA, Roberto. O Movimento dos Conceitos na Antropologia. Revista de Antropologia, n. 36, p. 13-31, 1993.

CARRIER, James G. (Org.). Occidentalism. Oxford: Claredon Press; Oxford University Press, 2003. 
Fabiano Gontijo

CASTRO-GÓMEZ, Santiago. El Tonto y los Canallas. Bogotá: Editorial Pontifícia Universidade Javeriana, 2019.

CHAKRABARTY, Dipesh. Habitations of Modernity: Essays in the wake of subaltern studies. Chicago: The University of Chicago Press, 2002.

CHAKRABARTY, Dipesh. Provincializing Europe. Princeton: Princeton University Press, 2007.

COLE, Catherine M.; MANUH, Takyiwaa; MIESCHER, Stephan M. (Orgs.). Africa After Gender? Indianapolis: Indiana University Press, 2007.

CURRIER, Ashley. Out in Africa: LGBT Organizing in Namibia and South Africa. Minneapolis: University of Minnesota Press, 2012.

DABASHI, Hamid. Brown Skin, White Masks. Londres: Pluto Press, 2001.

DAS, Veena; POOLE, Deborah. State and Its Margins: Comparative Ethnographies. In: DAS, Veena; POOLE, Deborah (Orgs.). Anthropology in the Margins of State. New Delhi: Oxford University Press, 2004. p. 3-33.

DIAS, Juliana Braz; BELIZZE, Geovanna. Encenando a Diferença em Palcos Metropolitanos: As trajetórias de Sarah Baartman e Franz Taibosh. Anuário Antropológico, v. 45, n. 3, p. 304-324, 2020. Available at: https://doi.org/10.4000/aa.6697. Access on: 5 May 2020.

DIESEL, Alleyn (Org.). Reclaiming the L-world: Sappho's daughters out in Africa. Cidade do Cabo: Modjaji Books, 2011.

DONHAM, Donald L. Freeing South Africa: The "modernization" of male-male sexuality in Soweto. Cultural Anthropology, v. 13, n. 1, p. 3-21, 1998. Available at: https://www. jstor.org/stable/656686?seq=1. Access on: 5 May 2020.

DORLIN, Elsa (Org.). Sexe, Race, Classe: Pour une épistémologie de la domination. Paris: PUF, 2009.

DORLIN, Elsa. La Matrice de la Race. Généalogie sexuelle et coloniale de la nation française. Paris: La Découverte, 2006.

DUDINK, Stefan. Les Nationalismes Sexuels et l'Histoire Raciale de l'Homosexualité. Raisons Politiques, v. 49, n. 1, p. 43-54, 2013. Available at: https://www.cairn.info/revue-raisons-politiques-2013-1-page-43.htm. Access on: 5 May 2020.

DURANTI, Andrea. 2008. Gay but Not Queer: Defining liminal post-queer identities in Maghrebian literature. Contemporary French and Francophone Studies, v. 12, n. 1, p. 79-87. Available at: https://www. tandfonline.com/doi/ abs/10.1080/17409290701793034?journalCode=gsit20. Access on: 5 May 2020.

EKINE, Sokari. Narrativas Contestadoras da África Queer. Cadernos de Gênero e Diversidade, v. 2, n. 2, p. 10-14, 2016. Available at: https://portalseer.ufba.br/index.php/ cadgendiv/article/view/20727. Access on: 5 May 2020.

EKINE, Sokari; ABBAS, Hakima (Orgs.). Queer African Reader. Oxford: Pambuzuka Press, 2013.

ELIAS, Norbert. O Processo Civilizador. Rio de Janeiro: Zahar, 1994.

ELLISON, Marvin M. Erotic Justice: A liberating ethic of sexuality. Louisville: Westminster John Knox Press, 1996.

EPPRECHET, Marc. Sexuality and Social Justice in Africa. Londres: Zed Books, 2013.

EPPRECHT, Marc. "Hidden" Histories of African Homosexualities. Canadian Woman Studies / Les Cahiers de la Femme, v. 24, n. 2-3, p. 138-144, 2005. Available at: https:// 
Fabiano Gontijo

core.ac.uk/reader/230900048. Access on: 5 May 2020.

EPPRECHT, Marc. Heterosexual Africa? The history of an idea from the age of exploration to the age of AIDS. Athens: Ohio University Press, 2008a.

EPPRECHT, Marc. New Perspectives on Sexualities in Africa: Introduction. Canadian Journal of African Studies, v. 43, n. 1, p. 1-7, 2009. Available at: https://www.tandfonline.com/doi/abs/10.1080/00083968. 2010.9707579. Access on: 5 May 2020.

EPPRECHT, Marc. Unspoken Facts: A history of homosexualities in Africa. Harare: Gays and Lesbians of Zimbabwe, 2008b.

EPPRECHT, Marc; MURRAY, Stephen O.; ANDAM, Kuukuwa; MIGUEL, Francisco; MBAYE, Aminate C.; GAUDIO, Rudolf P. Boy Wives, Female Husbands Twenty Years On: Reflections on scholarly activism and the struggle for sexual orientation and gender identity/expression rights in Africa. Canadian Journal of African Studies, v. 52, n. 3, p. 349-364, 2018. Available at: https://doi.org/10.1080/00083968.2018.1546604. Access on: 5 May 2020.

FANON, Frantz. Peau Noire, Masques Blancs. Paris: Seuil, 1952.

FAUSTO-STERLING, Anne. Sexing the Body: gender politics and the construction of sexuality. New York: Basic Books, 2000.

FERREIRA, Jonatas; HAMLIN, Cynthia. 2010. Mulheres, Negros e Outros Monstros: Um ensaio sobre corpos não civilizados. Revista Estudos Feministas, v. 18, n. 3, p. 811836. Available at: https://www.scielo.br/ pdf/ref/v18n3/v18n3a10.pdf. Access on: 5 May 2020.

FOUCAULT, Michel. História da Sexualidade. 1 A Vontade de Saber. Rio de Janeiro: Graal, 1999.

FOUCAULT, Michel. Microfísica do Poder. Rio de Janeiro: Graal, 1998.

FOUCAULT, Michel. Naissance de la Biopolitique. Cours au Collège de France (1978-1979). Paris: Gallimard; Seuil, 2004b.

FOUCAULT, Michel. O Sujeito e o Poder. In: DREYFUS, Hubert; RABINOW, Paul (Orgs.). Michel Foucault - Uma trajetória filosófica. Rio de Janeiro: Forense, 1995. p. 229-249.

FOUCAULT, Michel. Sécurité, Territoire, Population. Cours au Collège de France (19771978). Paris: Gallimard; Seuil, 2004a.

GALZ - GAYS AND LESBIANS OF ZIMBABWE. Sahwira: Being gay and lesbian in Zimbabwe. Harare: GALZ, 1995.

GARGALLO, Francesca. Feminismo desde Abya Yala. Cidade do México: s/e, 2014.

GAUDIO, Rudi. Male Lesbians and Other Queer Notions in Hausa. In: Stephen O. Murray \& Will Roscoe (Orgs.). Boy Wives and Female Husbands: Studies in African homosexualities. New York: St. Martin's Press, 1998. p. 111-128.

GAUDIO, Rudolf P. Allah Made Us: Sexual outlaws in an Islamic African city. Malden: Wiley-Blackwell. 2009.

GEVISSER, Mark; CAMERON, Edwin (Orgs.). Defiant Desire: Gay and lesbian lives in South Africa. New York: Routledge, 1995.

GILROY, Paul. O Atlântico Negro. São Paulo: Ed. 34, 2001.

GONTIJO, Fabiano. Intersexualidade, Bioantropologia/Bioarqueologia e Poder. Bagoas, v. 12, n. 18, p. 48-73, 2018. Available at: https://periodicos.ufrn.br/bagoas/article/ view/14403. Access on: 5 May 2020.

GONTIJO, Fabiano; ARISI, Barbara; FERNANDES, Estêvão. Queer Natives in Latin Ameri- 
ca. Cham: Springer, 2020.

GONTIJO, Fabiano; SCHAAN, Denise. Sexualidade e Teoria Queer: Apontamentos para a arqueologia e a antropologia brasileiras. Revista de Arqueologia, v. 30, n. 2, p. 5170. 2017. Available at: https://revista. sabnet.org/index.php/SAB/article/view/544. Access on: 5 May 2020.

GORDON-CHIPEMBERE, Natasha (Org.). Representation and Black Womanhood: The legacy of Sarah Baartman. New York: Palgrave Macmillan, 2011.

GUEBEGUO, Charles. L'Homosexualité en Afrique: Sens et variations d'hier à nos jours. Socio-Logos, n. 1, s/p, 2006a. Available at: https://journals.openedition.org/socio-logos/37. Access on: 5 May 2020.

GUEBEGUO, Charles. La Question Homosexuelle en Afrique: Le cas du Cameroun. Paris: L'Harmattan, 2006b.

GUEBOGUO, Charles. Les Sexualités Africaines dans leurs Nouvelles Perspectives: Introduction. Canadian Journal of African Studies, v. 43, n. 1, p. 8-11, 2009. Available at: https://www.tandfonline.com/doi/abs/ 10.1080/00083968.2010.9707580. Access on: 5 May 2020.

GUNKEL, Henriette. Some Reflections on Postcolonial Homophobia, Local Interventions, and LGBTI Solidarity Online: The politics of global petitions. African Studies Review, v. 56, n. 2, p. 67-81, 2013. Available at: https://muse.jhu.edu/article/519184. Access on: 5 May 2020.

GUNKEL, Henriette. The Cultural Politics of Female Sexuality in Africa. New York: Routledge, 2010.

HAN, Enze; O'MAHONEY, Joseph. British Colonialism and the Criminalization of Homosexuality: Queens, crime and empire. Londres: Routledge, 2018.

HAYES, Jarrod. Queer Nations: Marginal sexualities in the Maghreb. Chicago: University of Chicago Press, 2000.

HERDT, Gilbert (Org.). Moral Panics, Sex Panics. New York: New York University Press, 2009.

HOAD, Neville. African Intimacies: Race, homosexuality, and globalization. Minneapolis: University of Minnesota Press, 2007.

HOLMES, Rachel. African Queen: The real life of the Hottentot Venus. New York: Penguin Random, 2009.

HYAM, Ronald. Empire and Sexual Opportunity. Manchester: Manchester University Press, 1991.

IRELAND, Patrick R. A Macro-Level Analysis of the Scopes, Causes, and Consequences of Homophobia in Africa. African Studies Review, v. 56, n. 2, p. 47-66, 2013. Available at: https://muse.jhu.edu/article/519183. Access on: 5 May 2020.

IZUGBARA, C. Otutubikey. Patriarchal ideology and Discourses of sexuality in Nigeria. Understanding Human Sexuality Seminar Series 2. Lagos: ARSRC, 2004. Available at: http://www.arsrc.org/downloads/uhsss/ izugbara.pdf. Access on: 5 May 2020.

JACKSON, Peter A. Global Queering and Global Queer Theory: Thai (trans)genders and (homo)sexualities in world history. Autrepart, v. 49, n. 1, p. 15-30, 2009. Available at: https://www.cairn.info/revue-autrepart-2009-1-page-15.htm. Access on: 5 May 2020.

JAUNAIT, Alexandre; LE RENARD, Amélie; MARTEAU, Élisabeth. Nationalismes Sexuels? Reconfigurations contemporaines des sexualités et des nationalismes. Raisons Poli- 
tiques, v. 49, n. 1, p. 5-23, 2013. Available at: https://www.cairn.info/revue-raisonspolitiques-2013-1-page-5.htm. Access on: 5 May 2020.

JUNGAR, Katarina; OINAS, Elina. Preventing HIV? Medical Discourses and invisible women. In: ARNFRED, Signe (Org.). Re-Thinking Sexualities in Africa. Upsala: Nordiska Afrikainstitutet, 2004. p. 97-114.

KAOMA, Kapya. Globalizing the Culture Wars: American conservatives, African churches and homophobia. Somerville: Political Research Associates, 2009.

KAPUR, Ratna. Erotic Justice: Law and the new politics of postcolonialism. Londres: Glasshouse Press, 2005.

KROUSE, Matthew (Org.). The Invisible Ghetto: Lesbian \& gay writing from South Africa. Joanesburgo: COSAW, 1993.

LACHHEB, Monia (Org.). Ettre Homosexuel au Maghreb. Paris: Karthala, 2016.

LANDER. Edgardo. A Colonialidade do Saber. Buenos Aires: CLACSO, 2005.

LANGA, Ercílio Neves B. A Homossexualidade no Continente Africano: História, colonização e debates contemporâneos. Cadernos de África Contemporânea, v. 1, n. 2, p. 52-72, 2018. Available at: http://www.capoeirahumanidadeseletras.com.br/ojs-2.4.5/ index.php/cac/article/view/145. Access on: 5 May 2020.

LARMARANGE, Joseph; DESGRÉES DU LOU, Annabel; ENEL, Catherine; WADE, Abdoulaye. Homosexualité et Bisexualité au Sénégal. Population, 64 (4): 723-56. 2009. Available at: https://www.jstor.org/stable/ 40608431?seq=1. Access on: 5 May 2020.

LEVINE, Philippa (Org.). Gender and Empire. Oxford: Oxford University Press, 2007.

LIMA, Fátima. Bio-Necropolítica. Arquivos Brasileiros de Psicologia, v. 70 (no.spe.), p. 20-33, 2018. Available at: http://pepsic.bvsalud.org/scielo.php?script=sci_arttext\&pid=S1809-52672018000400003\& Ing=pt\&nr m=iso\&tlng=pt. Access on: 5 May 2020.

LOOMBA, Ania; KAUL, Suvir; BUNZI, Matti; BURTON, Antoinette; ESTY, Jed (Orgs.). Postcolonial Studies and Beyond. Durham: Duke University Press, 2005.

M'BAYE, Babacar. The Origins of Senegalese Homophobia: Discourses on homosexuals and transgender people in colonial and postcolonial Senegal. African Studies Review, v. 56, n. 2, p. 109-128, 2013. Available at: https://muse.jhu.edu/article/519186. Access on: 5 May 2020.

MAFEJE, Archie. A Commentary on Anthropology and Africa. Codesria Bulletin, n. 3-4, p. 88-94, 2008. Available at: https://www.codesria.org/spip.php?article508\&lang=en. Access on: 5 May 2020.

MAFEJE, Archie. Anthropology in Post-Independence Africa. Nairobi: Heinrich Böll Foudantion, 2001.

MALDONADO-TORRES, Nelson. Analítica da Colonialidade e da Decolonialidade. In: BERNARDINO-COSTA, Joaze; MALDONADO-TORRES, Nelson; GROSFOGUEL, Ramón (Orgs.). Decolonialidade e Pensamento Afro-Diaspórico. Belo Horizonte: Autêntica, 2018. p. 27-54.

MALOMALO, Bas'llele. Decolonialidade Africana/Negra: Uma crítica pan-africana construtiva. Capoeira, v. 5, n. 2, p. 115-140, 2019. Available at: http://www.capoeirahumanidadeseletras.com.br/ojs-2.4.5/index. php/capoeira/article/view/211. Access on: 5 May 2020.

MARTIN, Karin; MAKHOSAZANA, Xaba (Orgs.). Queer Africa: New and collected fiction. 
Fabiano Gontijo

Joanesburgo: MaThoko's Brooks, 2013.

MASSAD, Joseph. Desiring Arabs. Chicago: University of Chicago Press, 2007.

MASSAD, Joseph. Re-Orienting Desire: The Gay International and the arab world. Public Culture, v. 14, n. 2, p. 361-85, 2002. Available at: https://muse.jhu.edu/article/26284. Access on: 5 May 2020.

MATEBENI, Zethu (Org.). Reclaiming Afrikan: Queer perspectives on sexual and gender identities. Athlone: Modjaji Books, 2014.

MATEBENI, Zethu. Exploring Black Lesbian Sexualities and Identities in Johannesburg. Tese (Doutorado em Filosofia) - University of Witwatersrand, Joanesburgo, 2011.

MATEBENI, Zethu; MONRO, Surya; REDDY, Vasu (Orgs.). Queer in Africa: LGBTQI identities, citizenship, and activism. Londres: Routledge, 2018.

MBEMBE, Achille. À Propos des Écritures Africaines de Soi. Politique Africaine, $\mathrm{n}$. 77, p. 16-43, 2000. Available at: https://www.cairn.info/revue-politique-africaine-2000-1-page-16.htm. Access on: 5 May 2020.

MBEMBE, Achille. De La Postcolonie: Essai sur l'imagination politique dans l'Afrique contemporaine. Paris: Karthala, 2005.

MBEMBE, Achille. Le Potentat Sexuel: À propos de la sodomie, de la fellation et autres privautés postcoloniales. Le Messager / Africultures, 13/02/2006, s/p. Available at: http://africultures.com/le-potentat-sexuel-a-propos-de-la-sodomie-de-la-fellationet-autres-privautes-postcoloniales-4296/. Access on: 5 May 2020.

MBEMBE, Achille. Necropolítica. São Paulo: n-1 Edições, 2018.

MBISI, Thabo. The Lies We Have Been Told: On (homo)sexuality in Africa. Africa Today, v. 58, n. 1, p. 54-77, 2011. Disponível: http://web-b-ebscohost.ez3.periodicos. capes.gov.br/ehost/detail/detail?vid=3\&sid= a71135cf-c71b-4876-8de0-0717d07 75abe\%40pdc-v-sessmgr04\&bdata=Jmxhbmc9cHQtYnImc2l0ZT1laG9z dC1saXZl\#AN=66358070\&db=sih. Access on: 5 May 2020.

MBURU, John. Awakenings: Dreams and delusions of an incipient lesbian and gay movement in Kenya. In: Peter Drucker (Org.). Different Rainbows. Londres: Gay Men's Press, 2000. p. 179-191.

MCCLINTOK, Anne. Imperial Leather: Race, gender, and sexuality in the colonial conquest. New York: Routledge, 1995.

MIESCHER, Stephan F. Making Men in Ghana. Indianapolis: Indiana University Press, 2005.

MIGNOLO, Walter (Org.). Género y Descolonialid. Buenos Aires: Ediciones del Siglo, 2008.

MIGNOLO, Walter. The Darker Side of Western Modernity: Global futures, decolonial options. Durham; Londres: Duke University Press, 2011.

MIGUEL, Francisco. (Homo)Sexualidades Masculinas em Cabo Verde: Um caso para pensar teorias antropológicas e movimento LGBT em África. Enfoques, v. 15, n. 1, p. 87-110, 2016b. Available at: https://revistas.ufrj.br/index.php/enfoques/issue/ view/847/showToc. Access on: 5 May 2020.

MIGUEL, Francisco. "Hiprocrisia”: A visão dos gays cabo-verdianos sobre o seu próprio sistema de gênero. ACENO: Revista de Antropologia do Centro-Oeste, v. 3, n. 5, p. 259276, 2016a. Available at: http://periodicoscientificos.ufmt.br/ojs/index.php/aceno/ article/view/3276. Access on: 5 May 2020.

MIGUEL, Francisco. "Levam Má Bô”: (Homo)sexualidades entre os sampadjudus da Ilha 
de São Vicente de Cabo Verde. Dissertação (Mestrado em Antropologia Social) -Universidade de Brasília, Brasília, 2014.

MIGUEL, Francisco. Maríyarapaxjis: Silêncio, exogenia e tolerância nos processos de institucionalização das homossexualidades masculinas em Moçambique. Tese (Doutorado em Antropologia Social) - Universidade de Brasília, Brasília, 2019.

MORGAN, Ruth; WIERINGA, Saskia (Orgs.). Tommy Boys, Lesbian Men, and Ancestral Wives: Female same-sex practices in Africa. Joanesburgo: Jacana, 2005.

MOUTINHO, Laura. Cooperação Internacional, Parcerias Acadêmicas e Afeto na Perspectiva Sul-Sul. Revista Estudos Feministas, v. 27, n. 3, p. 1-9, 2019. Available at: https://www.jstor.org/stable/26851993? seq=1.. Access on: 5 May 2020.

MUDIMBE, Valentin-Yves. A Invenção da África. Luanda: Pedago, 2013.

MURRAY, Stephen O. (Org.). Latin American Male Homosexualities. Albuquerque: University New Mexico Press, 1995.

MURRAY, Stephen O.; ROSCOE, Will. Boy Wives and Female Husbands: Studies in African homosexualities. New York: St. Martin's Press, 1998.

MURRAY, Stephen O.; ROSCOE, Will. Islamic Homosexualities. New York: New York University Press, 1997.

N'DIAYE, Tidiane. La Longue Marche des Peuples Noirs. Paris: Publibook, 2006.

NDJIO, Basile. Post-Colonial Histories of Sexuality: The political invention of a libidinal African straight. Africa: The Journal of the International Institute, v. 82, n. 4, p. 609-631, 2012. Available at: https://www.cambridge.org/core/journals/africa/ article/postcolonial-histories-of-sexuality-the-political-invention-of-a-libidinal-african-straight/667F1D4787779B54B0CABBBEF8A90490. Access on: 5 May 2020.

NIANG, Cheikh Ibrahim; DIAGNE, Moustapha; NIANG, Youssoupha; MOREAU, Amadou Mody (Orgs.). Meeting the Sexual Health Needs of Men Who Have Sex with Men in Senegal. Washington: USAID, 2002.

NKOLI, Simon. Wardrobes: Coming out as a black gay activist in South Africa. In: GEVISSER, Mark; CAMERONB, Edwin (Orgs.). Defiant Desire: Gay and lesbian lives in South Africa. Joanesburgo: Ravan, 1994. p. 249-257.

NYANZI, Stella. Unpacking the [Govern]Mentality of African Sexualities. In: TAMALE, Sylvia (Org.). African Sexualities: A reader. Cidade do Cabo: Pambazuka, 2011. p. 477-501.

NYECK, Sybille N.; EPPRECHT, Marc. Sexual Diversity in Africa: Politics, theory, citizenship. Montréal: McGill-Queen's University Press, 2013.

OMBOLO, J.-P. Sexe et Société en Afrique Noire. Paris: L'Harmattan, 1990.

OYĚWÙMÍ, Oyèrònké. The Invention of Women: Making an African sense of western gender discourse. Minneapolis: University of Minnesota Press, 1997.

PEIRETTI-COURTIS, Delphine. Sexe, Race et Médecine: Anatomie et sexualité des Africain-e-s sous l'oeil des médecins français (1780-1950). Emulations, n. 15, p. 45-58, 2015. Available at: https://ojs.uclouvain.be/ index.php/emulations/article/view/4963. Access on: 5 May 2020.

PUAR, Jasbir K. Terrorist Assemblage: homonationalism in queer times. Durham: Duke University Press, 2007.

PURI, Jyoti. Encountering Nationalism. Malden: Blackwell Publishing, 2004.

QUIJANO, Aníbal. Colonialidad del Poder y Clasificación Social. Journal of World-Systems Research, v. 6, n. 2, p. 342-386, 2000. Available at: http://jwsr.pitt.edu/ojs/jwsr/ 
Fabiano Gontijo

article/view/228. Access on: 5 May 2020.

QURESHI, Sadiah. Displaying Sarah Baartman, the "Hottentot Venu". History of Science, v. 42, n. 2, p. 233-257, 2004. Available at: https://journals.sagepub.com/doi/ pdf/10.1177/007327530404200204. Access on: 5 May 2020.

RATELE, Kopana. Analysing Males in Africa: Certain useful elements in considering ruling masculinities. African and Asian Studies, v. 7, n. 4, p. 515-536, 2008. Available at: https://www.deepdyve. com/lp/brill/analysing-males-in-africa-certain-useful-elements-in-considering-elgWLNtKJt?key=brill. Access on: 5 May 2020.

REA, Caterina. Narrativas e Contra-Narrativas Africanas sobre a Dissidência Sexual. Capoeira, v. 5, n. 2, p. 142-154, 2019. Available at: http://www.capoeirahumanidadeseletras.com.br/ojs-2.4.5/index.php/ capoeira/article/view/212. Access on: 5 May 2020.

REA, Caterina. Sexualidades Dissidentes e Teoria Queer Pós-Colonial: O caso africano. Epistemologias do Sul, v. 1, n. 1, p. 145-165, 2017. Available at: https://revistas.unila. edu.br/epistemologiasdosul/article/ view/775.. Access on: 5 May 2020.

REA, Caterina; FONSECA, João Bosco S.; SILVA, Ana C. B. B. (Orgs.). Traduzindo a África Queer II. Salvador: Devires, 2020.

REA, Caterina; PARADIS, Clarisse G.; AMANCIO, Izzie M. S. (Orgs.). Traduzindo a África Queer. Salvador: Devires, 2018.

READ, Graeme. How to Be a "Real Gay": Gay identities in small-town South Africa. Scottsville: KwaZulu-Natal Press, 2013.

REBUCINI, Gianfranco. 2013. Masculinités Hégémoniques et « Sexualités » entre Hommes au Maroc. Cahiers d'Études Africaines, v. 209/210, n. 1-2, p. 387-415, 2013. Available at: https://journals. openedition.org/etudesafricaines/17367. Access on: 5 May 2020.

REBUCINI, Gianfranco. Les Masculinités au Maroc. Pour une Anthropologie des Genres et des Sexualités dans la Ville de Marrakech. Tese (Doutorado em Etnologia e Antropologia Social) - École de Hautes Études en Sciences Sociales - EHESS, Paris, 2009.

REDDY, Vasu; SANDFORT, Theo; RISPEL, Laetitia (Orgs.). From Social Silence to Social Science: Same-sex sexuality, HIV \& AIDS and Gender in South Africa. Cidade do Cabo: HSRC, 2009.

RESTREPO, Eduardo; ESCOBAR, Arturo. "Other Anthropology and Anthropology Otherwise": steps to a world anthropologies framework. Critique of Anthropology, v. 25, n. 2, p. 99-129, 2005. Disponível em https://journals.sagepub.com/ doi/10.1177/0308275X05053009. Access on: 5 May 2020.

SAID, Edward. Orientalismo. São Paulo: Companhia das Letras, 1990.

SANDFORT, Theo; SIMENEL, Fabienne; MWACHIRO, Kevin; REDDY, Vasu (Orgs.). Boldly Queer: African perspectives on same-sex sexuality and gender diversity. Amsterdam: Hivos, 2015.

SANTOS, Boaventura de Sousa. Para Além do Pensamento Abissal. Revista Crítica de Ciências Sociais, n. 78, p. 3-46, 2007.

SAVARESE, Eric. Domination Coloniale, Violence Physique et Violence Symbolique. Revue Méditerranéenne d'Études Politiques, n. 3, p. 121-138, 1996.

SCHMITT, Arno; SOFER, Jehoeda (Orgs.). Sexuality and Eroticism in Moslem Societies. New York: Routledge, 2013 [1992].

SEDGWICK, Eve K. Epistemology of the Closet. Berkeley: University of California Press, 
1990.

SPRONK, Rachel. Ambiguous Pleasure: Sexuality and middle-class self-perceptions in Nairobi. New York: Berghahn Books, 2012.

SPRONK, Rachel; HENDRIKS, Thomas. Readings in Sexualities from Africa. Bloomington: Indiana University Press, 2020.

STOLER, Ann L. Carnal Knowledge and Imperial Power: Race and the intimate in colonial rule. Berkeley: University of California Press, 2002.

STOLER, Ann L. Race and the Education of Desire: Foucault's History of Sexuality and the colonial orders of things. Durham: Duke University Press, 1995.

TAMALE, Sylvia (Org.). African Sexualities: A reader. Cidade do Cabo: Pambazuka Press, 2011.

TAMALE, Sylvia. Confronting the Politics of Nonconforming Sexualities in Africa. African Studies Review, v. 56, n. 2, p. 31-45, 2013. Available at: https://www.cambridge.org/ core/journals/african-studies-review/article/confronting-the-politics-of-nonconforming-sexualities-in-africa/ E2E9BC2E3CFE66C5CDC848EE2C7BC275. Access on: 5 May 2020.

TAMALE, Sylvia. Homosexuality: Perspectives from Uganda. Kampala: Fountain Publishers, 2007.

TEUNIS, Niels. Same-Sex Sexuality in Africa: A case study from Senegal. AIDS and Behavior, v. 5, n. 2, p. 173-82, 2001. Available at: https://link.springer.com/article/10.1023/A:1011335129358. Access on: 5 May 2020.

TRABELSI, Salah. L'Esclavage dans l'Orient Musulman au ler/VIle et IVe/Xe siècles. In: COTTIAS, Myriam; CUNIN, Elisabeth; MENDES, António de A. (Orgs.). Les Traites et les Esclavages. Paris: Karthala, 2010.

TRABELSI, Salah. Travail et Esclavage: Y a-t-il eu un modèle oriental? Rives Méditerranéennes, n. 53, p. 21-39, 2016. Available at: https://www.cairn.info/revue-rives-mediterraneennes-2016-2.htm. Access on: 5 May 2020.

TUCKER, Andrew. Queer Visibilities: Space, identity and interaction in Cape Town. Malden: Wiley-Blackwell, 2009.

VANITA, Ruth. Queering India: Same-sex love and eroticism in Indian culture and society. Londres: Routledge, 2002.

WALLERSTEIN, Immanuel. Comprendre le Monde: introduction à l'analyse des systèmes-monde. Paris: La Découverte, 2006.

WIERINGA, Saskia; SIVORÍ, Horacio (Orgs.). The Sexual History of the Global South: Sexual politics and postcolonialism in Africa, Asia and Latin America. Londres: Zed Books, 2013.

WOLTERSDOFF, Volker. Neoliberalism and Its Homophobic Discontents. InterAlia: Pismo Poświęcone Studiom Queer, n. 2, p. 1-8, 2006-2007. Available at: https://interalia. queerstudies.pl/en/issue-2-2007/. Access on: 5 May 2020. 